\section{SOI: 1.1/TAS DOI: 10.15863/TAS International Scientific Journal Theoretical \& Applied Science}

p-ISSN: 2308-4944 (print)

e-ISSN: 2409-0085 (online)

Year: 2017

Issue: 09

Volume: 53

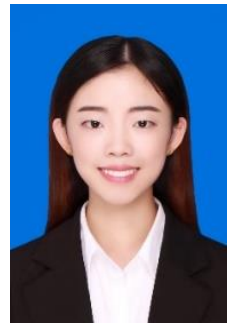

Min Du

Graduate student,

Business School of

Nanjing Normal University,

Nanjing, China

18260061590@163.com

SECTION 31. Economic research, finance, innovation, risk management.

\title{
STUDY ON THE RELATIONSHIP AMONG MONEY SUPPLY, AND INFLATION ECONOMIC GROWTH: BASE ON THE STATISTIC DATA 1990-2015 IN CHINA
}

Abstract: Relationship among money supply, and inflation economic growth is always a hot topic in academic world. In order to test the new phenomenon in them, Pearson correlation analysis and multiple regression analysis were used to analyze the internal relations among money supply, economic growth and inflation. Money supply and economic growth have high correlation ship, when money supply is high, the economy in China always in period of economic overheating. CPI cannot fully explain inflation in China inflation index should take house price and other elements in to consider.

Key words: Relationship, Money supply, Inflation, Economic growth.

Language: English

Citation: Du M (2017) STUDY ON THE RELATIONSHIP AMONG MONEY SUPPLY, AND INFLATION ECONOMIC GROWTH: BASE ON THE STATISTIC DATA 1990-2015 IN CHINA. ISJ Theoretical \& Applied Science, 09 (53): 60-67.

Soi: http://s-o-i.org/1.1/TAS-09-53-10 Doi: crossef https://dx.doi.org/10.15863/TAS.2017.09.53.10

\section{Introduction}

Since 1990s, China has come into a period with rapid economic growth, which called the second spring of Reform and Opening up. Although the recent economic growth rate is slower than 1990s and 2000s, Chinese economic growth rate is still relatively high compared to the world economy growth. There are many reasons for the rapid growth of Chinese economy, and the money supply is one of the key factors to Chinese economy growth. In the early 1990s, Chinese inflation rate is relatively high than before, but after 1996 Chinese economy achieved soft-landing successfully, Chinese inflation rate became lower and stable until now. However, the amount of Chinese money supply became bigger and bigger with stable inflation rate. These phenomena are deserved to analyze.

Relationship between money supply and economic growth is a hot topic in academic circle. Existing research can be divided into the following aspects: firstly, some researches argue that money supply is affected by economic growth, such as F Takahashi (1971) found the ratio of outside money to the money supply will be influenced by inflation and ultimately the long-run equilibrium values of the real variables in a fully employed economy; secondly, some researches argue that money supply has no significant relationship with economic growth by empirical analysis (Xie, C. et al 2009); some researches argue that influence between cash in circulation and economic growth is not stable, sometimes positive, sometimes negative effect, which means there were interactions between money supply and economic growth in China (Zhou, C. 2013). With regard to Money Supply, Economic Growth and Inflation, Wang (2012) found that there is no cointegration relationship among money supply, inflation, and economic growth, but there is cointegration relationship between money supply and inflation while there is no co-integration relationship between money supply and economic growth. Jiang (2014) studied shocks of economic growth and money supply on inflation use empirical analysis of the United States and China, japan and South Korea, and found that major currency supply shock on inflation is less than that of each country economic growth.

After Chinese economy has entered a new normal, the relationship among money supply, economic growth and inflation appeared new characteristics, so this topic is still need to research and explore. 


\begin{tabular}{l|lrl|l|ll} 
& ISRA (India) & $=\mathbf{1 . 3 4 4}$ & SIS (USA) & $=\mathbf{0 . 9 1 2}$ & ICV (Poland) & $=\mathbf{6 . 6 3 0}$ \\
Impact Factor: & ISI (Dubai, UAE) $=\mathbf{0 . 8 2 9}$ & PUHL (Russia) $=\mathbf{0 . 2 0 7}$ & PIF (India) & $=\mathbf{1 . 9 4 0}$ \\
& GIF (Australia) & $\mathbf{0 . 5 6 4}$ & ESJI (KZ) & $=3.860$ & IBI (India) & $=\mathbf{4 . 2 6 0}$ \\
& JIF & $\mathbf{1 . 5 0 0}$ & SJIF (Morocco) & $=\mathbf{2 . 0 3 1}$ & & \\
\hline
\end{tabular}

\section{Materials}

China Statistical Yearbook is the most authoritative source of data. Money Supply, economic growth and inflation data can all be found in China Statistical Yearbook, and the data is the complete time series, which can be used conveniently.

Money Supply is the total amount of monetary assets available in an economy at a specific time. The standard measures usually include currency in circulation and demand deposits (depositors' easily accessed assets on the books of financial institutions). In economic research M2 (including currency, demand deposits, and small denomination time deposits) is often used as object of study, so in this paper M2 was used as money supply data. The following tables show the money supply amounts and growth rates from the year 1990-2015.

The money supply amount from the year 1990-2015.

Table1

\begin{tabular}{lccc}
\hline Year & M2 (CNY) & Year & M2 (CNY) \\
\hline 1990 & 15293 & 2003 & 221223 \\
1991 & 19350 & 2004 & 254107 \\
1992 & 25402 & 2005 & 298756 \\
1993 & 34880 & 2006 & 345578 \\
1994 & 46924 & 2007 & 403442 \\
1995 & 60751 & 2008 & 475167 \\
1996 & 76095 & 2009 & 610225 \\
1997 & 90995 & 2010 & 725852 \\
1998 & 104499 & 2011 & 851591 \\
1999 & 119898 & 2012 & 974149 \\
2000 & 134610 & 2013 & 1106525 \\
2001 & 158302 & 2014 & 1228375 \\
2002 & 185007 & 2015 & 1392278 \\
\hline
\end{tabular}

Table 2

The money supply growth rate in each year from 1990-2015.

\begin{tabular}{cccc}
\hline Year & M2 growth rate $(\%)$ & Year & M2 growth rate $(\%)$ \\
\hline 1990 & 15.7 & 2003 & 19.6 \\
1991 & 26.5 & 2004 & 14.7 \\
1992 & 31.3 & 2005 & 17.6 \\
1993 & 37.3 & 2006 & 16.9 \\
1994 & 34.5 & 2007 & 16.7 \\
1995 & 29.5 & 2008 & 17.8 \\
1996 & 25.3 & 2009 & 28.5 \\
1997 & 17.3 & 2010 & 19.7 \\
1998 & 14.8 & 2011 & 13.6 \\
1999 & 14.7 & 2012 & 13.8 \\
2000 & 12.3 & 2013 & 13.6 \\
2001 & 14.4 & 2014 & 12.2 \\
2002 & 16.8 & 2015 & 13.3 \\
\hline
\end{tabular}




\begin{tabular}{|c|c|c|c|c|c|c|}
\hline Impact Factor: & $\begin{array}{l}\text { ISRA (India) } \\
\text { ISI (Dubai, UAE } \\
\text { GIF (Australia) } \\
\text { JIF }\end{array}$ & $\begin{array}{r}=1.344 \\
=0.829 \\
=0.564 \\
=1.500\end{array}$ & $\begin{array}{l}\text { SIS (USA) } \\
\text { PИНЦ (Russia) } \\
\text { ESJI (KZ) } \\
\text { SJIF (Morocco) }\end{array}$ & $\begin{array}{l}=0.912 \\
=0.207 \\
=\mathbf{3 . 8 6 0} \\
=\mathbf{2 . 0 3 1}\end{array}$ & $\begin{array}{l}\text { ICV (Poland) } \\
\text { PIF (India) } \\
\text { IBI (India) }\end{array}$ & $\begin{array}{l}=6.630 \\
=1.940 \\
=4.260\end{array}$ \\
\hline
\end{tabular}

From those two table above we can found that the amount of money supply is quite big during the past years, and has several cycles. There are at least 3 cycles during those years, and the year 1993, 2003, 2009 are the peak year respectively in each cycles. Most economists agree that money supply is directly related to inflation (Sims, 1980), so according this kind of viewpoints the inflation would be quite high during the past years, while interestingly the inflation in China is always much lower than money supply and always in controllable range. The following tables show the inflation rates from the year 19902015.

Inflation rates from the year 1990-2015.

\begin{tabular}{lccc}
\hline Year & Inflation rate $(\%)$ & Year & Inflation rate(\%) \\
\hline 1990 & 3.1 & 2003 & 1.2 \\
1991 & 3.4 & 2004 & 3.9 \\
1992 & 6.4 & 2005 & 1.8 \\
1993 & 14.7 & 2006 & 1.5 \\
1994 & 24.1 & 2007 & 4.8 \\
1995 & 17.1 & 2008 & 5.9 \\
1996 & 8.3 & 2009 & -0.7 \\
1997 & 2.8 & 2010 & 3.3 \\
1998 & -0.8 & 2011 & 5.4 \\
1999 & -1.4 & 2012 & 2.6 \\
2000 & 0.4 & 2013 & 2.6 \\
2001 & 0.7 & 2014 & 2.0 \\
2002 & -0.8 & 2015 & 1.4 \\
\hline
\end{tabular}

From the table above we can found that except the year 1993, 1994, 1995, the inflation rate was relatively high, other years the inflation rates were all lower than 10\%, and even the year 1998, 1999, 2002, 2009 , the inflation rate is negative. This phenomenon reveal that China retain a reasonable inflation rate. From the year 1992 to 1996 is the most serious
Table 3

overheated economy period in China, and in 1996 Chinese economy has made a soft landing. From the tables below show that Chinese economy has basically achieved high growth with low inflation, which can be called a miracle in world economic history.

Chinese GDP from the year 1990-2015.

Table 4

\begin{tabular}{lccc}
\hline Year & GDP $($ CNY $)$ & Year & GDP $(\mathrm{CNY})$ \\
\hline 1990 & 18872.9 & 2003 & 137422.0 \\
1991 & 22005.6 & 2004 & 161840.2 \\
1992 & 27194.5 & 2005 & 187318.9 \\
1993 & 35673.2 & 2006 & 219438.5 \\
1994 & 48637.5 & 2007 & 270232.3 \\
1995 & 61339.9 & 2008 & 319515.5 \\
1996 & 71813.6 & 2009 & 349081.4 \\
1997 & 79715.0 & 2010 & 413030.3 \\
1998 & 85195.5 & 2011 & 489300.6 \\
1999 & 90564.4 & 2012 & 540367.4 \\
2000 & 100280.1 & 2013 & 595244.4 \\
2001 & 110863.1 & 2014 & 643974.0 \\
2002 & 121717.4 & 2015 & 685505.8 \\
\hline
\end{tabular}

ISPC Innovations in science, 


\begin{tabular}{l|lrl|l|ll} 
& ISRA (India) & $=\mathbf{1 . 3 4 4}$ & SIS (USA) & $=\mathbf{0 . 9 1 2}$ & ICV (Poland) & $=\mathbf{6 . 6 3 0}$ \\
Impact Factor: & ISI (Dubai, UAE) $=\mathbf{0 . 8 2 9}$ & PUHU (Russia) $=\mathbf{0 . 2 0 7}$ & PIF (India) & $=\mathbf{1 . 9 4 0}$ \\
& GIF (Australia) & $\mathbf{0 . 5 6 4}$ & ESJI (KZ) & $=\mathbf{3 . 8 6 0}$ & IBI (India) & $\mathbf{4 . 2 6 0}$
\end{tabular}

Chinese GDP growth from the year 1990-2015.

Table 5

\begin{tabular}{cccc}
\hline Year & GDP growth rate $(\%)$ & Year & GDP growth rate $(\%)$ \\
\hline 1990 & 9.8 & 2003 & 12.9 \\
1991 & 16.6 & 2004 & 17.8 \\
1992 & 23.6 & 2005 & 15.7 \\
1993 & 31.2 & 2006 & 17.1 \\
1994 & 36.3 & 2007 & 23.1 \\
1995 & 26.1 & 2008 & 18.2 \\
1996 & 17.1 & 2009 & 9.3 \\
1997 & 11.0 & 2010 & 18.3 \\
1998 & 6.9 & 2011 & 18.5 \\
1999 & 6.3 & 2012 & 10.4 \\
2000 & 10.7 & 2013 & 10.2 \\
2001 & 10.6 & 2014 & 8.2 \\
2002 & 9.8 & 2015 & 6.4 \\
\hline
\end{tabular}

From the table above we can found that China has experienced rapid economic growth for more than 30 years, the GDP in 2015 is 36 times than GDP in 1990, and only six years of growth is below double digits in those 36 years.

\section{Methods}

Although from the description of the data money supply, inflation, and economic growth looks like discrepant, their internal relations still need metrical study. Pearson correlation analysis and multiple regression analysis were used to analyze the internal relations among money supply, economic growth and inflation. In statistics, the Pearson correlation coefficient is a measure of the linear correlation between two variables $\mathrm{X}$ and $\mathrm{Y}$. It has a value between +1 and -1 , where 1 is total positive linear correlation, 0 is no linear correlation, and -1 is total negative linear correlation (Stigler, 1989). It is used to study the correlation ship between money supply and inflation, money supply and economic growth, inflation and economic growth. In addition to Pearson correlation analysis, multiple regression analysis used to discover the causal relationship among money supply, inflation, and economic growth. In statistical modeling, regression analysis is a set of statistical processes for estimating the relationships among variables (Armstrong, 2012).

\section{Results} variables

1. Pearson correlation analysis between each

In this part, money supply, inflation, and economic growth were described by M2, CPI and GDP, and they were analysis in pairs.

\section{Pearson correlation between money supply and inflation.}

Table 6

Correlations

\begin{tabular}{|ll|r|r|}
\hline & & M2 & \multicolumn{1}{|c|}{ CPI } \\
\hline M2 & Pearson correlation & 1 & -.270 \\
& Significance (2-tailed) & & .182 \\
& $\mathrm{~N}$ & 26 & 26 \\
\hline $\mathrm{CPI}$ & Pearson correlation & -.270 & 1 \\
& Significance (2-tailed) & .182 & \\
& $\mathrm{~N}$ & 26 & 26 \\
\hline
\end{tabular}




\begin{tabular}{|c|c|c|c|c|c|c|}
\hline Impact Factor: & $\begin{array}{l}\text { ISRA (India) } \\
\text { ISI (Dubai, UAF } \\
\text { GIF (Australia) } \\
\text { JIF }\end{array}$ & $\begin{array}{l}=1.344 \\
=0.829 \\
=0.564 \\
=1.500\end{array}$ & $\begin{array}{l}\text { SIS (USA) } \\
\text { PИНЦ (Russia) } \\
\text { ESJI (KZ) } \\
\text { SJIF (Morocco) }\end{array}$ & $\begin{array}{l}=0.912 \\
=0.207 \\
=\mathbf{3 . 8 6 0} \\
=\mathbf{2 . 0 3 1}\end{array}$ & $\begin{array}{l}\text { ICV (Poland) } \\
\text { PIF (India) } \\
\text { IBI (India) }\end{array}$ & $\begin{array}{l}=6.630 \\
=1.940 \\
=4.260\end{array}$ \\
\hline
\end{tabular}

The table above indicate that the correlation ship is low between money supply and inflation, and

the correlation ship is not significant due to P-Value.

Pearson correlation between money supply and economic growth.

Table 7

\begin{tabular}{|ll|r|r|}
\hline \multicolumn{1}{|c|}{ Correlations } \\
\hline M2 & Mearson Correlation & 1 & \multicolumn{1}{|c|}{ GDP } \\
\hline & Sig. (2-tailed) & & $.096^{* *}$ \\
& $\mathrm{~N}$ & 26 & 26 \\
\hline GDP & Pearson Correlation & $.996^{* *}$ & 1 \\
& Sig. (2-tailed) & .000 & \\
& $\mathrm{~N}$ & 26 & 26 \\
\hline
\end{tabular}

The table above indicate that the correlation ship is quite high between money supply and GDP, and the correlation ship is significant due to P-Value.

Table 8

Pearson correlation between inflation and economic growth.

\begin{tabular}{|ll|r|r|}
\hline \multicolumn{3}{|c|}{ Correlations } \\
\hline \multirow{5}{*}{ Inflation } & CPI & \multicolumn{1}{c|}{ GDP } \\
& Pearson Correlation & 1 & -.271 \\
& Sig. (2-tailed) & & .180 \\
& $\mathrm{~N}$ & 26 & 26 \\
\hline GDP & Pearson Correlation & -.271 & 1 \\
& Sig. (2-tailed) & .180 & \\
& $\mathrm{~N}$ & 26 & 26 \\
\hline
\end{tabular}

The table above indicate that the correlation ship is low between inflation and economic growth, and the correlation ship is not significant due to PValue.

2. Multiple regression analysis between each variables
In this part, money supply, inflation, and economic growth were treated as dependent variable respectively to use multiple regression analysis to identify the causal relationship among money supply, inflation, and economic growth.

Multiple regression analysis use money supply as dependent variable.

Model Summary
\begin{tabular}{|l|r|r|r|r|}
\hline Model & R & R Square & $\begin{array}{c}\text { Adjusted R } \\
\text { Square }\end{array}$ & $\begin{array}{c}\text { Std. Error of } \\
\text { the Estimate }\end{array}$ \\
\hline 1 & $.996^{\mathrm{a}}$ & .992 & .991 & 38600.8904 \\
\hline
\end{tabular}

a. Predictors: (Constant), GDP, Inflation

ANOVA $^{b}$

\begin{tabular}{|ll|r|r|r|r|r|}
\hline \multicolumn{1}{|c|}{ Model } & Sum of Squares & \multicolumn{1}{c|}{ df } & Mean Square & \multicolumn{1}{c|}{ F } & \multicolumn{1}{c|}{ Sig. } \\
\hline 1 & Regression & $4.232 \mathrm{E} 12$ & 2 & $2.116 \mathrm{E} 12$ & 1420.061 & $.000^{\mathrm{a}}$ \\
& Residual & $3.427 \mathrm{E} 10$ & 23 & $1.490 \mathrm{E} 9$ & & \\
& Total & $4.266 \mathrm{E} 12$ & 25 & & & \\
\hline
\end{tabular}

a. Predictors: (Constant), GDP, Inflation

b. Dependent Variable: M2 


\begin{tabular}{|c|c|c|c|c|c|c|}
\hline Impact Factor: & $\begin{array}{l}\text { ISRA (India) } \\
\text { ISI (Dubai, UAE } \\
\text { GIF (Australia) } \\
\text { JIF }\end{array}$ & $\begin{array}{r}=1.344 \\
=0.829 \\
=0.564 \\
=1.500\end{array}$ & $\begin{array}{l}\text { SIS (USA) } \\
\text { PИНЦ (Russia) } \\
\text { ESJI (KZ) } \\
\text { SJIF (Morocco }\end{array}$ & $\begin{array}{l}=\mathbf{0 . 9 1 2} \\
=\mathbf{0 . 2 0 7} \\
=\mathbf{3 . 8 6 0} \\
=\mathbf{2 . 0 3 1}\end{array}$ & $\begin{array}{l}\text { ICV (Poland) } \\
\text { PIF (India) } \\
\text { IBI (India) }\end{array}$ & $\begin{array}{l}=6.630 \\
=1.940 \\
=4.260\end{array}$ \\
\hline
\end{tabular}

\begin{tabular}{|c|c|c|c|c|c|c|}
\hline \multicolumn{7}{|c|}{ Coefficients $^{\mathbf{a}}$} \\
\hline \multirow{2}{*}{\multicolumn{2}{|c|}{ Model }} & \multicolumn{2}{|c|}{ Unstandardized Coefficients } & $\begin{array}{l}\text { Standardized } \\
\text { Coefficients }\end{array}$ & \multirow[b]{2}{*}{$\mathrm{t}$} & \multirow[b]{2}{*}{ Sig. } \\
\hline & & $\mathrm{B}$ & Std. Error & Beta & & \\
\hline 1 & (Constant) & -59564.620 & 13953.063 & & -4.269 & .000 \\
\hline & CPI & -11.231 & 1355.887 & .000 & -.008 & .993 \\
\hline & GDP & 1.955 & .038 & .996 & 51.294 & .000 \\
\hline
\end{tabular}

a. Dependent Variable: M2

The tables above indicate that the multiple regression equation is fitting well, since the $\mathrm{R}$ squire is almost 1 , and the significant level is quite low. The coefficient of GDP is positive, while the CPI is negative. The CPI coefficient is contrary to economic theory.

Multiple regression analysis use inflation as dependent variable.

Table 10

\section{Model Summary}

\begin{tabular}{|l|r|r|r|r|}
\hline Model & $\mathrm{R}$ & R Square & $\begin{array}{c}\text { Adjusted R } \\
\text { Square }\end{array}$ & $\begin{array}{c}\text { Std. Error of } \\
\text { the Estimate }\end{array}$ \\
\hline 1 & $.271^{\mathrm{a}}$ & .074 & -.007 & 5.9362 \\
\hline
\end{tabular}

a. Predictors: (Constant), GDP, M2

ANOVA ${ }^{b}$

\begin{tabular}{|c|c|c|c|c|c|c|}
\hline \multicolumn{2}{|c|}{ Model } & $\begin{array}{l}\text { Sum of } \\
\text { Squares }\end{array}$ & df & Mean Square & F & Sig. \\
\hline \multirow[t]{3}{*}{1} & Regression & 64.312 & 2 & 32.156 & .913 & $.416^{\mathrm{a}}$ \\
\hline & Residual & 810.488 & 23 & 35.239 & & \\
\hline & Total & 874.800 & 25 & & & \\
\hline
\end{tabular}

a. Predictors: (Constant), GDP, M2

b. Dependent Variable: CPI

\section{Coefficients $^{\mathrm{a}}$}

\begin{tabular}{|c|c|c|c|c|c|c|}
\hline \multirow{2}{*}{\multicolumn{2}{|c|}{ Model }} & \multicolumn{2}{|c|}{ Unstandardized Coefficients } & $\begin{array}{l}\text { Standardized } \\
\text { Coefficients }\end{array}$ & \multirow[b]{2}{*}{$\mathrm{t}$} & \multirow[b]{2}{*}{ Sig. } \\
\hline & & $\mathrm{B}$ & Std. Error & Beta & & \\
\hline \multirow[t]{3}{*}{1} & (Constant) & 6.083 & 2.578 & & 2.360 & .027 \\
\hline & M2 & $-2.656 \mathrm{E}-7$ & .000 & -.019 & -.008 & .993 \\
\hline & GDP & $-7.103 \mathrm{E}-6$ & .000 & -.253 & -.113 & .911 \\
\hline
\end{tabular}

a. Dependent Variable: CPI

The tables above indicate that the multiple regression equation is not fitting well, since the $R$ squire is almost 0 , and the significant level is big. The coefficients are also meaningless. 


\begin{tabular}{|c|c|c|c|c|c|c|}
\hline Impact Factor: & $\begin{array}{l}\text { ISRA (India) } \\
\text { ISI (Dubai, UAE } \\
\text { GIF (Australia) } \\
\text { JIF }\end{array}$ & $\begin{array}{l}=1.344 \\
=0.829 \\
=0.564 \\
=1.500\end{array}$ & $\begin{array}{l}\text { SIS (USA) } \\
\text { PИНЦ (Russia) } \\
\text { ESJI (KZ) } \\
\text { SJIF (Morocco) }\end{array}$ & $\begin{array}{l}=0.912 \\
=0.207 \\
=\mathbf{3 . 8 6 0} \\
=\mathbf{2 . 0 3 1}\end{array}$ & $\begin{array}{l}\text { ICV (Poland) } \\
\text { PIF (India) } \\
\text { IBI (India) }\end{array}$ & $\begin{array}{l}=6.630 \\
=1.940 \\
=4.260\end{array}$ \\
\hline
\end{tabular}

Multiple regression analysis use economic growth as dependent variable.

Table 11

\begin{tabular}{|c|c|c|c|c|}
\hline \multicolumn{1}{|c}{ Model Summary } \\
\begin{tabular}{|c|c|c|c|c|}
\hline Model & R & R Square & $\begin{array}{c}\text { Adjusted R } \\
\text { Square }\end{array}$ & $\begin{array}{c}\text { Std. Error of } \\
\text { the Estimate }\end{array}$ \\
\hline 1 & $.996^{\mathrm{a}}$ & .992 & .991 & 19655.8596 \\
\hline
\end{tabular}
\end{tabular}

a. Predictors: (Constant), CPI, M2

\begin{tabular}{|rl|r|r|r|r|r|}
\hline \multicolumn{2}{|c|}{ ANOVA $^{\mathbf{b}}$} \\
Model & & Sum of & & & \\
Squares & df & Mean Square & F & Sig. \\
\hline 1 & Regression & $1.098 \mathrm{E} 12$ & 2 & $5.489 \mathrm{E} 11$ & 1420.849 & $.000^{\mathrm{a}}$ \\
& Residual & $8.886 \mathrm{E} 9$ & 23 & $3.864 \mathrm{E} 8$ & & \\
& Total & $1.107 \mathrm{E} 12$ & 25 & & & \\
\hline
\end{tabular}

a. Predictors: (Constant), CPI, M2

b. Dependent Variable: GDP

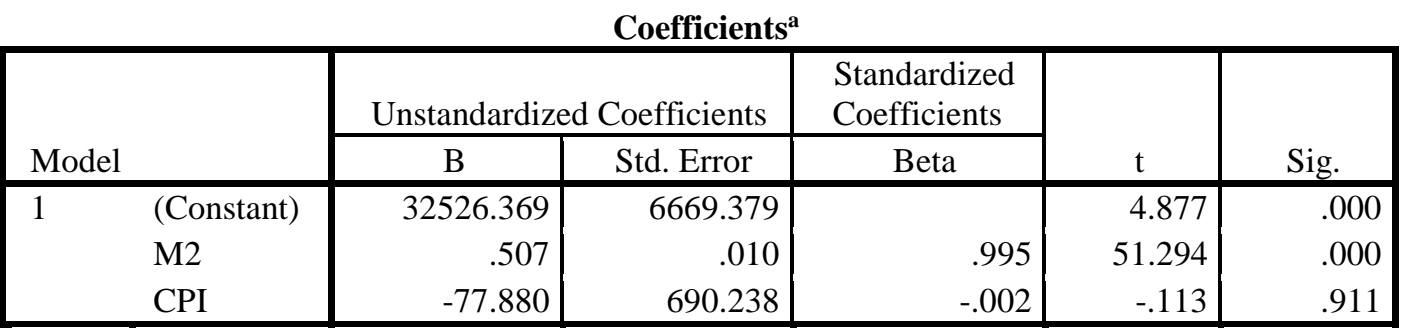

a. Dependent Variable: GDP

The tables above indicate that the multiple regression equation is fitting well, since the $\mathrm{R}$ squire is almost 1 , and the significant level is quite low. The coefficient of M2 is positive, while the CPI is negative. The CPI coefficient is contrary to economic theory, and the M2 coefficient is too low.

\section{Discussions}

Pearson correlation between money supply and inflation does not pass the significant test, and the Pearson correlation is low than 0.3 , which means there is no significant relationship between them. This phenomenon is not fit the classic economic theory (Chorafas, 2009), and the reason might be the CPI was always received government macro-control restrictions. Pearson correlation between money supply and economic growth is quite high, which means money supply and economic growth is high relevant. The rise in money supply is always accompanied by an overheating economy, and the decline in money circulation is always accompanied by economic contraction. Pearson correlation between inflation and economic growth is also low and cannot pass the significant test, and the problem may still come from CPI, because the calculation of
Chinese CPI is selective weighting without lots of important elements like the house price. So the CPI data cannot reveal the real price level in China.

Multiple regression fit use money supply as dependent variable with inflation and economic growth as independent variables has a high fitting degree. The coefficient of GDP is positive, which meet theoretical expectation ( $\mathrm{Lu}$, et al. 2017), while the coefficient of CPI is negative, which does not meet theoretical expectation, and the reason might be the same as the discussion of Pearson correlation analysis. Multiple regression fit use inflation as dependent variable does not show good fitting degree, both fitting degree and coefficient are meaningless according the classical theory. Multiple regression fit use economic growth as dependent variable has a good fitting level with bad coefficients, and the reason might be the factors that affect economic growth are numerous. Economic growth could not fully explained by only two elements.

\section{Conclusion}

Money supply and economic growth have high correlation ship, when money supply is high, the 


\begin{tabular}{l|lrl|l|ll} 
& ISRA (India) & $=\mathbf{1 . 3 4 4}$ & SIS (USA) & $=\mathbf{0 . 9 1 2}$ & ICV (Poland) & $=\mathbf{6 . 6 3 0}$ \\
Impact Factor: & ISI (Dubai, UAE) $=\mathbf{0 . 8 2 9}$ & PUHL (Russia) $=\mathbf{0 . 2 0 7}$ & PIF (India) & $=\mathbf{1 . 9 4 0}$ \\
& GIF (Australia) & $\mathbf{0 . 5 6 4}$ & ESJI (KZ) & $=3.860$ & IBI (India) & $=\mathbf{4 . 2 6 0}$
\end{tabular}

economy in China always in period of economic overheating, so money supply adjust can regulate economic overheating or contraction. Economic growth in China is influenced by money supply and other variables, money supply is only one factor of economic growth. CPI cannot fully explain inflation in China, so Pearson correlation and Multiple regression of CPI does not make enough sense, inflation index should take house price and other elements in to consider.

In the future research, new indicator of CPI will be created to do the analysis, more measurement methods will be used to do the test, and panel data formed by sub regional data will be used to promoted accuracy of the analysis.

\section{References:}

1. Takahashi F. (1971) Money supply and economic growth. Econometrica,39(2), 285303.

2. Xie C., Tang H., Cui Y. (2009) Money Supply, Economic Growth and Inflation of China: 19982007. International Joint Conference on Computational Sciences and Optimization (Vol.2, pp.562-566). IEEE.

3. Zhou C. (2013) Research on china's money supply and sustainable development of economic growth. International Journal of Applied Environmental Sciences.

4. Wang Y. (2012) Relationship research on money supply, economic growth and inflation. Journal of Convergence Information Technology, 7(11), 20-28.

5. Jiang M.H. (2014) Shocks of economic growth and money supply on inflation:an empirical analysis of the united states and china,japan and south korea under the gvar model. Contemporary Economy of Japan,64(5), 531-534.

6. Sims C.A. (1980) Macroeconomics and reality. Econometrica, 48(1), 1-48.

7. Stigler S.M. (1989) Francis galton's account of the invention of correlation. Statistical Science, 4(2), 73-79.

8. Armstrong J.S. (2012) Illusions in regression analysis. International Journal of Forecasting, 28(3), 689-694.

9. Chorafas D.N. (2009) Money Supply and Inflation. Capitalism Without Capital. Palgrave Macmillan UK.

10. Lu X., Guo K., Dong Z., Wang X. (2017) Financial development and relationship evolvement among money supply, economic growth and inflation: a comparative study from the u.s. and china. Applied Economics(10), 114. 